\title{
Validitas dan Kepraktisan Modul Bioinformatika Berbasis Problem-Based Learning untuk Mahasiswa S2 Biologi
}

\author{
Muhammad Khalil ${ }^{1}$, Mohamad Amin ${ }^{1}$, Betty Lukiati ${ }^{1}$ \\ ${ }^{1}$ Pendidikan Biologi-Universitas Negeri Malang
}

\begin{tabular}{l} 
INFO ARTIKEL \\
\hline Riwayat Artikel: \\
Diterima: 24-04-2019 \\
Disetujui: $18-05-2020$ \\
\hline
\end{tabular}

\section{Kata kunci:}

bioinformatics module; problem-based learning; validity; practicality; modul bioinformatika; problem-based learning; kevalidan; kepraktisan

\begin{abstract}
ABSTRAK
Abstract: The aims of this development research are to produce teaching materials in the form of bioinformatics module based on problem-based learning titled analysis of the potential of natural compounds in silico as drug candidates that meet the requirements for validity and practicality to be used in bioinformatics courses. The research method used is research and development method with ADDIE development model which consists of five stages. The validation test result by media experts, material experts, and field practitioners in sequentially obtained the percentage of $98.15 \%, 91.07 \%$, and $95.97 \%$. The practicality test results obtained a percentage of $87.46 \%$. The conclusion of this development research is the bioinformatics module that has been developed has met the requirements of validity and practicality and can be used without revision.
\end{abstract}

\begin{abstract}
Abstrak: Tujuan dari penelitian pengembangan ini adalah untuk menghasilkan bahan ajar berupa modul bioinformatika berbasis problem-based learning berjudul analisis potensi senyawa alami secara in silico sebagai kandidat obat yang memenuhi syarat kevalidan dan kepraktisan untuk dapat digunakan pada matakuliah bioinformatika. Metode penelitian yang digunakan berupa metode penelitian dan pengembangan (research and development) dengan model pengembangan ADDIE yang terdiri atas lima tahapan. Hasil uji validasi oleh ahli media, ahli materi dan praktisi lapangan secara berurutan diperoleh persentase 98.15\%, 91.07\%, dan 95.97\%. Hasil uji kepraktisan diperoleh persentase $87.46 \%$. Kesimpulan dari penelitian pengembangan ini adalah modul bioinformatika yang telah dikembangkan telah memenuhi syarat kevalidan dan kepraktisan serta dapat digunakan tanpa perlu revisi.
\end{abstract}

\author{
Alamat Korespondensi: \\ Muhammad Khalil \\ Pendidikan Biologi \\ Universitas Negeri Malang \\ Jalan Semarang 5 Malang \\ E-mail: mohdkhalil@outlook.com
}

Bioinformatika adalah kajian ilmu yang bersifat interdisiplin yang merupakan perpaduan biologi molekul, matematika dan Teknik informasi. Bioinformatika juga diartikan sebagai penggunaan dari alat komputasi untuk melakukan analisis dan menginterpretasikan data data biologi molekuler (Bayat, 2002). Kajian bioinformatika terdiri atas tiga unsur kegiatan, yaitu pusat data atau database, analisis data, dan prediksi (Witarto \& Sajidan, 2010). Bioinformatika merupakan kajian yang terus berkembang dan memberikan dampak terhadap kemajuan bioteknologi (Kumar \& Chordia, 2017; Tripathi, 2000). Bioinformatika telah diaplikasikan untuk memecahkan permasalahan melalui berbagai penelitian yang dilakukan, seperti mencari senyawa untuk terapi antivirus (Speck-Planche \& Natalia D. S. Cordeiro, 2011), mengidentifikasi pathway yang menyebabkan timbulnya suatu penyakit (Barrenäs, 2012), dan aplikasi dari bioinformatika dalam mencari, mendesain, dan mengembangkan obat (Shah, Rathod, Basuri, Modi, \& Parmar, 2015).

Pemanfaatan bioinformatika dalam mengembangkan obat dilakukan dengan pendekatan in silico. Pendekatan ini melibatkan penggunaan perangkat komputasi yang dikombinasikan dengan ketersediaan database yang menghasilkan strategi baru dalam melakukan analisis. Pendekatan in silico mampu menghasilkan prediksi terkait dengan pengembangan obat (Piñero, Furlong, \& Sanz, 2018). Kajian bioinformatika dengan pendekatan in silico memberikan dampak pada penghematan waktu dan biaya dalam proses penemuan obat dibandingkan dengan penemuan obat secara konvensional yang memerlukan waktu $5-7$ tahun bahkan lebih (Doom, Raymerand, \& Krane, 2004). Perkembangan bioinformatika yang semakin pesat juga telah mengefisiensikan waktu penelitian dengan menghilangkan eksperimen basah yang tidak perlu (Ouzounis, 2002). Manfaat dari pengaplikasian bioinformatika ini merupakan landasan untuk menjadikan bioinformatika sebagai kajian yang penting untuk dipelajari. 
Bioinformatika adalah salah satu matakuliah pilihan yang terdapat di program studi S2 Biologi Universitas Negeri Malang. Berdasarkan Rencana Perkuliahan Semester matakuliah bioinformatika, Capaian Pembelajaran yang hendak dicapai oleh mahasiswa adalah memahami hakikat dan prinsip-prinsip biologi molekular, prinsip dan prosedur dasar teknik molekular dalam bidang biologi, prinsip analisis data molelular berdasarkan karakteristik dan kegunaan analisis data dengan menggunakan teknologi informasi baik online maupun offline untuk pengembangan teknologi dalam rangka meningkatkan kesejahteraan manusia dan aspek pembelajarannya di perguruan tinggi dan sekolah menengah (Amin, 2018). Salah satu materi dalam bioinformatika yang diajarkan dalam pembelajaran tersebut adalah kajian in silico dan docking untuk penemuan kandidat obat. Namun dari observasi yang dilakukan terhadap pembelajaran, ditemukan adanya permasalahan yang dihadapi mahasiswa untuk mencapai CP yang telah ditentukan. 92\% mahasiswa menyatakan bahwa mengalami kesulitan dalam mengikuti perkuliahan. Kesulitan yang dihadapi mahasiswa terkait dengan materi pembelajaran (25\%), metode pembelajaran (16\%) dan sumber belajar $(67 \%)$. Berdasarkan informasi tersebut, diperlukan adanya upaya untuk menemukan solusi terkait permasalahan yang ada.

Salah satu upaya yang dapat dilakukan sebagai solusi terhadap permasalahan tersebut adalah dengan dilakukannya pengembangan suatu bahan ajar. Bahan ajar didefinisikan sebagai seperangkat alat/sarana yang digunakan dalam pembelajaran yang didalamnya berisikan materi, metode, batasan-batasan serta cara dalam melakukan evaluasi terhadap pembelajaran yang disusun secara menarik dan sistematis (Widodo \& Jasmadi, 2008). Berdasarkan hasil observasi, 92\% mahasiswa menginginkan bahan ajar berupa modul yang memuat informasi secara jelas dan lengkap terkait analisis bioinformatika untuk penemuan obat.

Modul didefinisikan sebagai salah satu bentuk bahan ajar yang di dalamnya terdapat seperangkat pengalaman belajar yang terencana, disusun secara lengkap dan sistematis serta dirancang untuk membantu mencapai tujuan pembelajaran secara efektif dan efisien (Daryanto, 2013). Ciri-ciri umum yang dimiliki oleh bahan ajar dalam bentuk modul, yaitu; terdapat pernyataan terkait tujuan/capaian pembelajaran pada bagian pendahuluan, pengetahuan/materi yang dituankan ke dalam modul disusun sedemikian rupa sehingga mahasiswa secara aktif berpartisipasi dalam pembelajaran, terdapat sistem penilaian berdasarkan penguasaan, materi dan penugasan disusun secara utuh, memberi kesempatan mencapai tujuan belajar tuntas untuk setiap mahasiswa (Parmin, 2009). Penggunaan modul dalam proses pembelajaran memiliki beberapa kelebihan, di antaranya bersifat fleksibel, meningkatkan rasa tanggungjawab peserta didik terhadap pembelajaran, asesmen dapat dilakukan sepanjang pembelajaran, memberikan feedback dari pembelajaran, dan memberikan kesempatan untuk mempelajari kembali materi dalam modul (Vidal Rodeiro \& Nádas, 2012; Mulyasa, 2005).

Modul yang dikembangkan pada penelitian pengembangan ini berupa modul bioinformatika yang berbasis model problem-based learning (Arend, 2012). Modul berbasis problem-based learning menggunakan permasalahan yang terdapat dalam kehidupan sehari-hari sebagai suatu konteks yang digunakan untuk melatih peserta didik dalam berpikir kritis dan memecahkan permasalahan. Selain itu, peserta didik juga memperoleh pengetahuan dan pemahaman konsep mengenai esensi dari materi yang dipelajari (Abdullah, Tarmizi, \& Abu, 2010; Akcay, 2009).

\section{METODE}

Penelitian pengembangan yang dilakukan menggunakan model pengembangan ADDIE (Branch, 2009) sebagai acuan yang memiliki lima tahapan, yaitu (1) menganalisis (analyse), (2) merancang (design), (3) mengembangkan (develop), (4) mengimplementasikan (implement), dan (5) mengevaluasi (evaluate). Pengembangan modul bioinformatika berbasis problembased learning berjudul analisis potensi senyawa alami secara in silico sebagai kandidat obat pada tahap pertama dilakukan analisis untuk mengetahui kesenjangan antara teori atau keadaan ideal dengan yang ada dalam pembelajaran. Tahap analisis membutuhkan identifikasi mendalam untuk mengusulkan solusi yang tepat agar dapat menyelesaikan permasalahan yang ada di dalam pembelajaran. Tahap kedua, perancangan terhadap produk berupa modul bioinformatika, melibatkan kegiatan untuk merancang seluruh komponen penyusun modul beserta perangkat untuk mengukur validitas dan kepraktisannya. Tahap ketiga, pengembangan modul dilakukan sesuai dengan rancangan yang telah ditentukan. Tahap keempat, dilakukan implementasi penggunaan modul pada mahasiswa. Tahap kelima, evaluasi dilakukan berdasarkan hasil validasi oleh validator ahli materi, ahli media, praktisi lapangan, dan mahasiswa secara menyeluruh. hasil evaluasi ini dijadikan acuan dalam melakukan revisi terhadap modul yang telah dikembangkan sehingga memenuhi kriteria kevalidan dan kepraktisan.

Validasi terhadap modul terdiri atas (1) validasi media yang dilakukan oleh ahli media dengan menggunakan instrumen berupa angket untuk mengetahui tingkat kevalidan modul berdasarkan aspek kegrafisan, kelengkapan dan karakteritik modul, (2) validasi materi yang dilakukan oleh ahli materi bioinformatika mengenai analisis potensi senyawa alami secara in silico sebagai kandidat obat dengan menggunakan instrumen berupa angket untuk mengetahui tingkat kevalidan materi dalam modul berdasarkan aspek kesesuaian materi dengan capaian pembelajaran (CP), keakuratan materi, kedalaman materi, kekontekstualan materi, kemutakhiran materi, kelayakan penyajian, dan kelayakan bahasa, dan (3) validasi yang dilakukan oleh praktisi lapangan dengan menggunakan instrumen angket untuk mengetahui tingkat kevalidan berdasarkan aspek kesesuaian dengan capaian pembelajaran (CP), keakuratan materi, penyajian materi, kebahasaan, dan penggunaan. Analisis data kevalidan modul dihitung menggunakan rumus berikut.

$$
\mathrm{PV}=\frac{T s p}{T s h} \mathrm{X} 100 \%
$$


Keterangan:

PV: Persentase kevalidan

Tsp: Total skor penilaian

Tsh: Total skor yang diharapkan

Data persentase yang diperoleh selanjutnya diinterpretasikan dengan menggunakan kriteria validitas yang diadaptasi dari Akbar (2013) yaitu pada tabel 1. Data persentase diperoleh selanjutnya diinterpretasikan dengan menggunakan kriteria kepraktisan yang diadaptasi dari Akbar (2013) yaitu pada tabel 2.

\section{Tabel 1. Kriteria Kevalidan Modul}

\begin{tabular}{cll}
\hline Skala Nilai \% & Keterangan & \multicolumn{1}{c}{ Keputusan Uji } \\
\hline $85,01-100,00$ & Sangat valid & Dapat digunakan, tidak perlu direvisi \\
$70,01-85,00$ & Valid & Dapat digunakan dengan revisi kecil \\
$50,01-70,00$ & Kurang valid & Dapat digunakan dengan revisi besar \\
$01,00-50,00$ & Tidak valid & Tidak dapat digunakan \\
\hline
\end{tabular}

Data tingkat kepraktisan dari modul yang telah dikembangkan diperoleh dari 12 responden yang merupakan mahasiswa yang mengikuti perkuliahan bioinformatika dengan menggunakan instrumen angket respons mahasiswa untuk mengetahui tingkat kepraktisan modul berdasarkan aspek tampilan, penyajian materi dan manfaat. Analisis data kepraktisan dihitung menggunakan rumus sebagai berikut.

$$
\mathrm{P}=\frac{\sum x}{\sum x i} \mathrm{X} 100 \%
$$

Keterangan:

P: Persentase

x: Skor dalam satu butir pertanyaan

xi: Skor maksimal dalam satu butir pertanyaan

Tabel 2. Kriteria Kepraktisan Modul

\begin{tabular}{cl}
\hline Skala Nilai \% & \multicolumn{1}{c}{ Keterangan } \\
\hline $81-100$ & Sangat praktis, dapat digunakan tanpa perlu direvisi \\
$61-80$ & Praktis, dapat digunakan namun perlu direvisi sedang \\
$41-60$ & Kurang praktis, disarankan tidak dipergunakan karena perlu revisi besar \\
$21-40$ & Tidak praktis atau tidak boleh digunakan \\
$0-20$ & Sangat tidak praktis, tidak boleh digunakan \\
\hline
\end{tabular}

\section{HASIL}

Hasil penelitian dan pengembangan berupa modul bioinformatika berjudul analisis potensi senyawa alami secara in silico sebagai kandidat obat diuji tingkat kevalidan dan kepraktisannya sehingga dapat digunakan dalam perkuliahan bioinformatika pada pembahasan materi kajian in silico dan docking untuk penemuan kandidat obat. Berikut disajikan hasil uji kevalidan yang dilakukan oleh ahli media, ahli materi, dan praktisi lapangan pada tabel 3.

\section{Tabel 3. Hasil Uji Kevalidan Modul}

\begin{tabular}{cllc}
\hline Validator & \multicolumn{1}{c}{ Aspek } & Persentase & Persentase Rata-rata \\
\hline Ahli Media & Kegrafisan & $98.4 \%$ & $98.15 \%$ \\
& Kelengkapan & $100 \%$ & \\
& Karakteristik & 96.06 & $91.07 \%$ \\
\hline Ahli Materi & Kesesuaian materi dengan CP & $83.33 \%$ & \\
& Keakuratan materi & $87.5 \%$ & \\
& Kedalaman materi & $100 \%$ & \\
& Kekontekstualan materi & $75 \%$ & \\
& Kemutakhiran materi & $91.67 \%$ & \\
& Kelayakan penyajian & $100 \%$ & \\
& Kelayakan bahasa & $100 \%$ & \\
& Kesesuaian dengan CP & $100 \%$ & \\
& Keakuratan materi & $91.67 \%$ & \\
& Penyajian materi & $93.75 \%$ & \\
& Kebahasaan & $100 \%$ & \\
& Penggunaan & $94.44 \%$ & \\
\hline
\end{tabular}


Hasil validasi yang dilakukan ahli media diperoleh rata-rata persentase sebesar $98.15 \%$ dengan kriteria sangat valid. Validasi oleh ahli materi diperoleh rata-rata persentase sebesar $91.07 \%$ dengan kriteria sangat valid. Validasi oleh praktisi lapangan diperoleh rata-rata persentase sebesar 95.97\% dengan kriteria sangat valid. Selain melakukan validasi berdasarkan aspek yang telah disediakan, validator ahli media, materi, dan praktisi lapangan juga memberikan komentar dan saran terhadap modul bioinformatika yang telah dikembangkan sebagai bahan pertimbangan untuk perbaikan modul. Adapun komentar dan saran tersebut disajikan pada tabel 4.

Tabel 4. Komentar dan Saran oleh Validator

\begin{tabular}{cl}
\hline Validator & \multicolumn{1}{c}{ Komentar dan Saran } \\
\hline Ahli Media & Secara umum media valid dan dapat dilanjutkan ke tahap berikutnya \\
\hline Ahli Materi & Sistematika penulisan perlu diperhatikan konsistensi penulisan beberapa istilah, seperti Mol Insporation/Mol Inpiration \\
\cline { 2 - 2 } & $\begin{array}{l}\text { Opsi pilihan jawaban benar pada soal evaluasi 1, no. 1 perlu diganti, karena "uji efektivitas senyawa" termasuk ke dalam } \\
\text { studi yang dapat dilakukan dengan aplikasi bioinformatika }\end{array}$ \\
\cline { 2 - 2 } & $\begin{array}{l}\text { Metode docking sebaiknya diberi penjelasan mengenai klasifikasinya berdasarkan pengaturan gridbox, yaitu metode } \\
\text { blind docking dan specific docking }\end{array}$ \\
\cline { 2 - 2 } & $\begin{array}{l}\text { Akan lebih baik dan menarik jika ditambahkan prosedur visualisasi hasil docking untuk melihat lebih detil sisi pengikatan } \\
\text { dan asam amino kunci pengikatan, misalnya dengan software Discovery Studio atau LigPlot }\end{array}$ \\
\hline Praktisi & Akan lebih baik jika memperjelas konsep docking yang digunakan, yaitu blind/specific docking \\
\cline { 2 - 3 } Lapangan & $\begin{array}{l}\text { Ditambahkan penggunaan software visualisasi pola pengikatan hasil docking sehingga memungkinkan untuk melihat } \\
\text { pola pengikatan, asam amino yang berikatan, serta kunci pengikatan dan jaraknya }\end{array}$ \\
\hline
\end{tabular}

Selain uji kevalidan yang dilakukan oleh validator ahli media, materi, dan praktisi lapangan, uji kepraktisan terhadap modul bioinformatika yang telah dikembangkan juga dilakukan dengan melibatkan 12 responden yang merupakan mahasiswa S2 Biologi yang mengikuti perkuliahan bioinformatika. Berikut disajikan hasil uji kepraktisan pada tabel 5.

Tabel 5. Hasil Uji Kepraktisan Modul

\begin{tabular}{clcc}
\hline Responden & \multicolumn{1}{c}{ Aspek } & Persentase & Persentase Rata-rata \\
\hline Mahasiswa & Tampilan & $89.17 \%$ & $87.46 \%$ \\
& Penyajian materi & $83.63 \%$ & \\
& Manfaat & $89.58 \%$ & \\
\hline
\end{tabular}

Hasil uji kepraktisan yang dilakukan oleh responden, diperoleh persentase rata-rata sebesar $87.46 \%$ dengan kriteria sangat praktis. Selain validasi berdasarkan aspek yang telah disediakan, responden juga dapat memberikan komentar dan saran yang akan dijadikan bahan pertimbangan untuk perbaikan modul. Berikut komentar dan saran yang diperoleh dari responden disajikan pada tabel 6.

Tabel 6. Komentar dan Saran oleh Responden

\begin{tabular}{ll}
\hline Responden & \multicolumn{1}{c}{ Komentar dan Saran } \\
\hline Mahasiswa & Modul cukup bagus dan jelas, saran untuk membahas lebih detail mengenai penggunaan ligan referensi \\
\cline { 2 - 2 } & Urutan langkah-langkah analisis lebih baik diberikan penomoran berurut, jangan menggunakan bullet \\
\cline { 2 - 2 } & Modul sudah baik, namun ada beberapa gambar yang perlu ditambahkan penunjuk menu mana yang harus dipilih/diklik \\
\cline { 2 - 2 } & $\begin{array}{l}\text { Modul disusun dengan baik karena memaparkan materi webserver dan database pada kegiatan I sehingga memberi } \\
\text { pemahaman awal untuk masuk ke materi docking }\end{array}$ \\
\cline { 2 - 2 } & Modul sudah baik dan menarik, membuat pembaca pemula tertarik. \\
\cline { 2 - 2 } & Banyak pengetahuan baru yang saya peroleh sebagai pemula dalam menggunakan software bioinformatika \\
\hline
\end{tabular}

\section{PEMBAHASAN}

Bahan ajar berupa modul yang dikembangkan untuk matakuliah bioinformatika berbasis pada masalah (problem-based learning), merupakan bahan ajar yang dipersiapkan untuk menunjang pembelajaran matakuliah tersebut. Untuk dapat digunakan dalam menunjang pembelajaran, suatu bahan ajar harus disusun berdasarkan kebutuhan mahasiswa dan tujuan pembelajaran yang hendak dicapai dalam pembelajaran (Daryanto, 2013). Oleh karena itu, diperlukan adanya upaya mengukur kredibilitas dari bahan ajar yang telah dikembangkan berdasarkan tingkat kevalidan maupun kepraktisannya (Levin, 1999). Tingkat kevalidan bahan ajar dapat ditentukan melalui uji validitas oleh validator yang kompeten dalam bidang pengembangan bahan ajar. Bahan ajar yang dapat ditetapkan memenuhi syarat kevalidan apabila terdapat kesesuaian antara komponen penyusun bahan ajar yang dikembangkan dengan tujuan pembelajaran (Fatmawati, 2016). Sementara itu, kepraktisan bahan ajar dapat ditentukan berdasarkan uji kepraktisan yang dilakukan pada mahasiswa sebagai responden yang mengikuti perkuliahan bioinformatika. Bahan ajar yang dapat ditetapkan memenuhi syarat kepraktisan apabila bahan ajar yang telah dikembangkan mudah dipahami dan diterapkan oleh mahasiswa (Nieveen, 1999). 
Uji kevalidan terhadap modul bioinformatika berbasis problem-based learning berjudul analisis potensi senyawa alami secara in silico sebagai kandidat obat yang telah dikembangkan dilakukan oleh validator ahli media, ahli materi dan praktisi lapangan. Validator ahli media melakukan validasi terhadap tiga aspek yang terdapat dalam modul, yaitu aspek kegrafisan modul (98.4\%), kelengkapan modul (100\%), dan karakteristik modul (96.06\%). Berdasarkan validasi media terhadap modul, diperoleh rata-rata persentase kevalidan dari aspek kegrafisan, kelengkapan dan karakteristik modul sebesar 98.15\%. Persentase tersebut dapat diinterpretasikan bahwa modul telah memenuhi syarat kevalidan berdasarkan hasil validasi oleh ahli media dengan memenuhi kriteria sangat valid tanpa perlu direvisi. Uji kevalidan juga dilakukan terhadap materi yang telah disajikan dalam modul. Validasi terhadap materi dalam modul dilakukan dengan memperhatikan tujuh aspek, yaitu kesesuaian materi dengan capaian pembelajaran (83.33\%), keakuratan materi (87.5\%), kedalaman materi (100\%), kekontekstualan materi (75\%), kemutakhiran materi (91.67\%), kelayakan penyajian (100\%) dan kelayakan bahasa (100\%). Hasil validasi materi diperoleh ratarata persentase kevalidan dari ketujuh aspek sebesar $91.07 \%$, menunjukkan bahwa materi yang disajikan dalam modul memenuhi kriteria sangat valid sehingga tidak diperlu dilakukan revisi terhadap materi yang terdapat dalam modul yang telah dikembangkan. Sedangkan validasi yang dilakukan oleh praktisi lapangan terhadap lima aspek yang terdapat dalam modul, meliputi kesesuaian dengan capaian pembelajaran (100\%), keakuratan materi (91.67\%), penyajian materi (93.75\%), kebahasaan (100\%), dan penggunaan $(94.44 \%)$, menunjukkan rata-rata persentase kevalidan sebesar $95.97 \%$ dengan kriteria sangat valid dan tidak perlu direvisi.

Uji kepraktisan yang dilakukan terhadap modul yang telah dikembangkan dilakukan oleh para responden, yaitu mahasiswa yang mengambil matakuliah bioinformatika. Responden melakukan penilaian terhadap tingkat kepraktisan modul berdasarkan tiga aspek yang terdapat didalamnya, yaitu aspek tampilan modul (89.17\%), penyajian materi (83.63\%), dan manfaat $(89.58 \%)$. Rata-rata persentase yang diperoleh dari penilaian tingkat kepraktisan modul berdasarkan ketiga aspek tersebut sebesar $87.46 \%$. Persentase tersebut mengindikasikan bahwa modul yang telah dikembangkan memenuhi kriteria sangat praktis, sehingga tidak perlu dilakukan revisi. Uji kepraktisan dilakukan untuk mengetahui respons dari mahasiswa terhadap produk berupa bahan ajar yang telah dikembangkan terhadap, misalnya tampilan, penyajian, dan penggunaan modul dalam kehidupan sehari-hari (Alfiriani, 2017).

Berdasarkan validasasi dan uji kepraktisan yang telah dilakukan oleh ahli media, ahli materi, praktisi lapangan, dan para responden, modul berbasis problem-based learning yang dikembangkan secara komprehensif telah memenuhi syarat kevalidan dan kepraktisan. Oleh karena itu, modul tersebut layak digunakan dalam memfasilitasi belajar mahasiswa. Diharapkan pula penggunaan modul mampu menunjang pembelajaran, meningkatkan keterampilan menganalisis, dan memecahkan masalah sesuai dengan tuntutan KKNI (Kemenristekdikti, 2015). Selain itu, modul diharapkan dapat meningkatkan kemampuan mahasiswa dalam menjawab tantangan abad 21 (Juliana, Amin, \& Suarsini, 2016), mampu meningkatkan kemampuan mahasiswa dalam menyelesaikan permasalahan (Leonda, Mohamad Ardian, Desnita, 2015) serta membantu mencapai kompetensi yang diharapkan (Wenno, 2017).

\section{SIMPULAN}

Hasil uji kevalidan terhadap modul bioinformatika berbasis problem-based learning yang dilakukan oleh validator ahli media, validator ahli materi dan praktisi lapangan, diperoleh persentase secara berurutan sebesar 98.15\%, 91.07\%, dan 95.97\% dengan kriteria sangat valid dan sudah dapat dipergunakan tanpa perlu revisi. Hasil uji kepraktisan diperoleh persentase sebesar 87.46\% dengan kriteria sangat praktis dan dapat dipergunakan tanpa perlu direvisi. Modul bioinformatika berbasis problem-based learning berjudul analisis potensi senyawa alami secara in silico sebagai kandidat obat yang telah memenuhi syarat kevalidan dan kepraktisan perlu diujikan secara eksperimental. Dengan demikian, hasil penelitian tersebut dapat digunakan sebagai acuan dalam penggunaan modul untuk skala yang lebih luas.

\section{DAFTAR RUJUKAN}

Abdullah, N. I., Tarmizi, R. A., \& Abu, R. (2010). The Effects of Problem Based Learning on Mathematics Performance and Affective Attributes in Learning Statistics at Form Four Secondary Level. Procedia - Social and Behavioral Sciences, 8(5), 370-376. https://doi.org/10.1016/j.sbspro.2010.12.052

Akbar, S. (2013). Instrumen Perangkat Pembelajaran. Bandung: PT. Remaja Rosdakarya.

Akcay, B. (2009). Problem-Based Learning in Science Education. Journal of Turkish Science Education, 6(1), $26-36$.

Alfiriani, A. (2017). Kepraktisan dan Keefektifan Modul Pembelajaran Bilingual Berbasis Komputer. Jurnal Kependidikan, $1(1), 12-23$.

Arend, R. I. (2012). Learning to Teach $9^{\text {th }}$ Edition. New York: McGraw-Hill.

Barrenäs, F. (2012). Bioinformatic identification of Disease Associated Pathways by Network Based Analysis. Sweden: Department of Clinical and Experimental.

Bayat, A. (2002). Science, Medicine, and the Future: Bioinformatics. BMJ (Clinical Research Ed.), 324(7344), 1018-1022. https://doi.org/10.1136/bmj.324.7344.1018

Branch, R. M. (2009). Instructional Design: The ADDIE Approach. New York: Springer International Publishing. Daryanto. (2013). Menyusun Modul: Bahan Ajar untuk Persiapan Guru Dalam Mengajar. Yogyakarta: Gava Media. 
Doom, T., Raymerand, M., \& Krane, D. (2004). Bioinformatics. IEEE Potentials, 23(1), 24-27. https://doi.org/10.1109/MP.2004.1266936

Fatmawati, A. (2016). Pengembangan Perangkat Pembelajaran Konsep Pencemaran Lingkungan menggunakan Model Pembelajaran Berdasarkan Masalah untuk SMA Kelas X. EduSains, 4(2), 94-103.

Juliana, K., Amin, M., \& Suarsini, E. (2016). Pengembangan Buku Ajar Matakuliah Biologi Sel dengan Pendekatan Bioinformatika untuk Mahasiswa S1 Universitas Negeri Malang. Jurnal Pendidikan: Teori, Penelitian, dan Pengembangan, 1(9), 1677-1683.

Kementrian Riset, Teknologi, dan Pendidikan Tinggi Republik Indonesia. (2015). Kerangka Kualifikasi Nasional Indonesia. Jakarta: Direktorat Jendral Pembelajaran dan Kemahasiswaan Kementerian Riset, Teknologi, dan Pendidikan Tinggi Republik Indonesia.

Kumar, A., \& Chordia, N. (2017). Role of Bioinformatics in Biotechnology. Research \& Reviews in BioSciences, 12(1), 1-6.

Leonda, Mohamad Ardian, Desnita, A. S. B. (2015). Pengembangan Modul Berbasis Problem Based Learning untuk Materi Usaha dan Energi Di SMA (Sesuai Kurikulum 2013). Prosiding Seminar Nasional Fisika (E-Journal), 4, $119-124$.

Levin, J. (1999). What to do About Educational Research's Credibility Gaps? Issues in Education, 5(2), $177-229$. https://doi.org/10.1016/S1080-9724(00)00025-2

Mulyasa. (2005). Menjadi Guru Profesional/Menciptakan Pembelajaran Kreatif dan Menyenangkan. Bandung: Remaja Rosda Karya.

Nieveen, N. (1999). Prototyping to Reach Product Quality. In Design Approaches and Tools in Education and Training (pp. 125-135). https://doi.org/10.1007/978-94-011-4255-7_10

Ouzounis, C. (2002). Bioinformatics and the Theoretical Foundations of Molecular Biology. Bioinformatics, 18(3), 377-378. https://doi.org/10.1093/bioinformatics/18.3.377

Parmin. (2009). Aktivitas Siswa Dalam Pembelajaran IPA melalui Lesson Study. Varia Pendidikan, $21(1), 11$.

Piñero, J., Furlong, L. I., \& Sanz, F. (2018). In Silico Models in Drug Development: Where We Are. Current Opinion in Pharmacology, 42, 111-121. https://doi.org/10.1016/j.coph.2018.08.007

Shah, V. A., Rathod, D. N., Basuri, T., Modi, V. S., \& Parmar, I. J. (2015). Applications of Bioinformatics in Pharmaceutical Product Designing: a Review. Virag et Al. World Journal of Pharmacy and Pharmaceutical Sciences, 4(1), 477.

Speck-Planche, A., \& Natalia D.S. Cordeiro, M. (2011). Application of Bioinformatics for the Search of Novel Anti-Viral Therapies: Rational Design of Anti-Herpes Agents. Current Bioinformatics, 6(1), 81-93. https://doi.org/10.2174/157489311795222392

Tripathi, K. K. (2000). Bioinformatics: The Foundation of Present and Future Biotechnology. Current Science, 79(5), $570-575$.

Vidal Rodeiro, C. L., \& Nádas, R. (2012). Effects of Modularity, Certification Session and Re-Sits on Examination Performance. Assessment in Education: Principles, Policy and Practice, 19(4), 411-430. https://doi.org/10.1080/0969594X.2011.614218

Wenno, I. H. (2017). Pengembangan Model Modul IPA Berbasis Problem Solving Method berdasarkan Karakteristik Siswa dalam Pembelajaran di SMP/MTs. Jurnal Cakrawala Pendidikan, 2(2), 176-188. https://doi.org/10.21831/cp.v2i2.338

Widodo, C. S., \& Jasmadi. (2008). Panduan Menyusun Bahan Ajar Berbasis Kompetensi. Jakarta: PT. Elex Media Komputindo

Witarto, A. B., \& Sajidan, S. (2010). Bioinformatika: Trend dan Prospek dalam Pengembangan Keilmuan Biologi. Prosiding Seminar Biologi, 7(1), 15-16. 